dr hab. inż. Bolesław Karwat, prof. AGH ${ }^{1}$

mgr inż. Artur Górski ${ }^{2}$

mgr inż. Emil Stańczyk ${ }^{1}$

Przyjęty/Accepted/Принята: 17.02.2014;

Zrecenzowany/Reviewed/Рецензирована: 12.02.2015;

Opublikowany/Published/Опубликована: 31.03.2015;

\title{
Badania reakcji czujek pożarowych w różnych warunkach pożaru
}

\author{
Testing the Reaction of Fire Detectors in Various Fire Conditions
}

Исследования реакции пожарных извещателей в различных условиях пожара

\begin{abstract}
A B S T R A K T
Cel: Celem przeprowadzonych badań było określenie przydatności czujek pożarowych do zastosowań w różnych warunkach pożaru, a także zweryfikowanie reakcji testowanych czujek na wymuszone zjawiska zwodnicze. W artykule przedstawiono przykłady najczęściej stosowanych czujek pożarowych, zakres ich stosowalności oraz technologię wykorzystywaną dla zabezpieczenia systemów sygnalizacji pożarowej przed działaniem zjawisk zwodniczych. W pracy omówiono wymagania stawiane nowoczesnym systemom sygnalizacji pożarowej. Wymieniono budynki oraz miejsca, w których istnieje obowiązek stosowania systemów sygnalizacji pożarowej zgodnie z obowiązującymi przepisami.

Metody: Wykonano badania reakcji czujek pożarowych w różnych warunkach pożaru oraz zbadano odpowiedź detektorów na działanie zjawisk zwodniczych. W trakcie badań dokonywano pomiaru czynników fizykochemicznych oraz szybkości reakcji detektorów na zaistniałe wymuszenie.

Do przeprowadzenia badań użyto czujek pożarowych powszechnie stosowanych w systemach sygnalizacji pożarowej przeznaczonych do różnych zastosowań. Czujki zostały rozmieszczone w odległości około 2 m od źródła symulowanego zagrożenia pożarowego. Przeprowadzono trzy testy, symulując: proces spawania, pożar tlący oraz pożar charakteryzujący się otwartym ogniem. Wykonując symulację zagrożenia pożarowego, dokonywano ciągłego pomiaru temperatury oraz stężenia dymu, a także reakcji czujek na zaistniałe wymuszenie.

Wyniki: Badania dowiodły, że tylko czujki wyposażone w nowoczesną technologię dynamicznego dostosowania parametrów do zmieniających się zjawisk pożarowych nadają się do szerokiego zakresu zastosowań, ponieważ zarówno pozwalają na szybsze wykrycie zaistniałego zagrożenia pożarowego, jak i umożliwiają większą odporność na zjawiska zwodnicze w porównaniu z tradycyjnymi czujkami.

Wnioski: Dzięki przeprowadzonym badaniom zweryfikowano, w jakim czasie dana czujka jest w stanie przejść ze stanu nieaktywnego w stan alarmu, dla określonych warunków pożarowych. Czas reakcji czujki na zaistniałe zagrożenie jest jednym z podstawowych parametrów określających użyteczność zastosowania danego detektora.

Przeprowadzone badania umożliwiły określenie przydatności stosowania czujek dla różnych warunków pożarowych. Dzięki wykonanym badaniom trafniej można dobrać czujkę do konkretnego zastosowania oraz z większym prawdopodobieństwem uniknąć fałszywych alarmów generowanych przez zjawiska zwodnicze.
\end{abstract}

Słowa kluczowe: bezpieczeństwo w budynkach, czujka pożarowa, zjawiska zwodnicze, systemy pożarowe Typ artykułu: oryginalny artykuł naukowy

\footnotetext{
Akademia Górniczo-Hutnicza im. Stanisława Staszica w Krakowie; karwat@agh.edu.pl / AGH University of Science and Technology, Poland;

2 Siemens Sp. z o.o. (Ltd.);

3 Autorzy wnieśli równy wkład merytoryczny w powstanie artykułu / The authors contributed equally to this article;
} 


\section{A B S T R AC T}

Aim: The purpose of the study was to determine the suitability of fire detectors for use in different fire conditions as well as verify the reaction of tested detectors to misleading trigger information. The paper describes examples of most frequently used fire detectors, their range of application and the technology harnessed to protect fire alarm systems from deceptive influences. The paper discussed modern fire alarm system requirements and the authors identified buildings, and locations, where installation of fire alarm systems is obligatory, in accordance with current regulations.

Methods: The reaction of fire detectors was tested in various fire conditions as well as their response to deceptive influences. During tests, measurements were performed on the chemical reaction and detector response speed upon receipt of input signals. Research investigations were performed on fire detectors in common use for a range of different needs. The detectors were distributed at a distance of about 2 metres from the source of a simulated fire hazard. There were three simulated testing conditions including: a welding process, a smouldering fire and an open fire. During the fire threat simulation, the temperature and smoke concentration as well as the sensors' activation response were constantly measured.

Results: Studies have revealed that only detectors equipped with modern technology, dynamically adapted to deal with a varied range of fire incidents, are suitable for general application. Mainly, because they afford faster detection of potential threats as well as provide greater protection against false activation compared with conventional detectors.

Conclusions: As a result of research it was possible to verify, for certain defined fire situations, the time lag for activation of a fire detector. The detector reaction time to a fire threat is one of the fundamental elements, which describe the usefulness of a given sensor. The study made it possible to determine the benefit in use of fire detectors for a range of different circumstances involving the threat of fire. As a result of research it is possible to select more accurately a detector for specific use and, with a higher level of probability, avoid false alarms caused by deceptive forces.

Keywords: safety in buildings, fire detector, deceptive events, fire systems Type of article: original scientific article

\section{АННОТАЦИЯ}

Цель: Целью проведенных исследований являлось определение пригодности пожарных извещателей для применения в разных условиях пожара, а также проверка реакции исследуемых извещателей на намеренно ложные явления. В статье представлены примеры чаще всего используемых пожарных извещателей, сфера их применения и технология, используемая для защиты установок обнаружения пожара от воздействия ложных явлений. В работе рассмотрены требования к современным системам обнаружения пожара. Перечислены здания и места, которые должны быть оснащены установками обнаружения пожаров согласно действующим правилам.

Методы: Проведены исследования реакции пожарных извещателей в разных условиях пожара и рассмотрены реакции детекторов на воздействие ложных явлений. В ходе исследований проверялись физко-химические факторы и время реакции детекторов на появившееся воздействие.

Для проведения исследований были использованы пожарные извещатели широко используемые в системах пожарной сигнализации, предназначенных для различных целей. Извещатели были размещены на расстоянии 2 метров от источника искусственного пожара. Были проведены три теста для имитации: процесса сварки, тлеющего огня и пожара с открытым огнём. Проводя симуляцию пожарной угрозы, беспрерывно измерялись температура и концентрация дыма, а также реакция извещателей на существующую ситуацию элементов в исследуемых покрытиях.

Результаты: Исследования подчеркнули, что только извещатели оборудованные современной технологией динамического адаптирования параметров к меняющимся обстоятельствам пожара, пригодны для широкого спектра применения, так как они позволяют быстрее обнаружить появившуюся угрозу пожара и более устойчивы к ложным явлениям, в сравнении с традиционными извещателями.

Выводы: Благодаря проведенным исследованиям было установлено время, за которое данный извещатель может сработать (перейти из неактивного режима к тревоге) в определенных условиях пожара. Время реакции извещателя на появившуюся угрозу является одним из основных параметров, определяющих необходимость применения данного извещателя.

Проведенные исследования позволили определить пригодность использования извещателей для разных условий пожара. Благодаря проведенным исследованиям можно более точно подобрать извещатель для конкретного применения и с большой вероятностью избежать тревоги, которая вызвана ложными явлением.

Ключевые слова: безопасность в зданиях, пожарный извещатель, ложные явления, противопожарные системы Вид статьи: оригинальная научная статья 


\section{Wstęp}

Zachowanie odpowiedniego poziomu bezpieczeństwa osób oraz mienia, odpowiednio wczesne wykrycie pożaru, minimalizacja strat, zniszczeń oraz ryzyka spowodowanego pożarem to podstawowe zadania systemów sygnalizacji pożarowej (SSP) stosowanych w nowoczesnych budynkach. Obowiązek stosowania systemów sygnalizacji pożarowej wyposażonych w urządzenia samoczynnego wykrywania i przekazywania informacji o pożarze, a także urządzenia odbiorcze alarmów pożarowych i sygnałów uszkodzeniowych reguluje Rozporządzenie Ministra Spraw Wewnętrznych i Administracji z dnia 7 czerwca 2010 r. w sprawie ochrony przeciwpożarowej budynków, innych obiektów budowlanych i terenów (Dz.U. $2010 \mathrm{nr}$ 109 poz. 719). W szczególności obowiązek stosowania SSP dotyczy budynków użyteczności publicznej takich jak:

- budynki handlowe lub wystawiennicze (jednokondygnacyjne o powierzchni strefy pożarowej powyżej $5000 \mathrm{~m}^{2}$, wielokondygnacyjne o powierzchni strefy pożarowej powyżej $2500 \mathrm{~m}^{2}$ ),

- teatry o liczbie miejsc powyżej 300,

- kina o liczbie miejsc powyżej 600,

- budynki o liczbie miejsc służących celom gastronomicznym powyżej 300,

- sale widowiskowo-sportowe o liczbie miejsc powyżej 1500,

- szpitale, z wyjątkiem psychiatrycznych, oraz sanatoria - o liczbie łóżek powyżej 200 w budynku,

- szpitale psychiatryczne o liczbie łóżek powyżej $100 \mathrm{w}$ budynku,

- domy pomocy społecznej i ośrodki rehabilitacji dla osób niepełnosprawnych o liczbie łóżek powyżej 100 w budynku,

- zakłady pracy zatrudniające powyżej 100 osób niepełnosprawnych w budynku,

- budynki użyteczności publicznej wysokie i wysokościowe,

- budynki zamieszkania zbiorowego, w których przewidywany okres pobytu tych samych osób przekracza trzy doby, o liczbie miejsc noclegowych powyżej 200,

- budynki zamieszkania zbiorowego niewymienione w poprzednim punkcie, o liczbie miejsc noclegowych powyżej 50,

- archiwa wyznaczone przez Naczelnego Dyrektora Archiwów Państwowych,

- muzea oraz zabytki budowlane, wyznaczone przez Generalnego Konserwatora Zabytków w uzgodnieniu z Komendantem Głównym Państwowej Straży Pożarnej,
- ośrodki elektronicznego przetwarzania danych o zasięgu krajowym, wojewódzkim i w urzędach obsługujących organy administracji rządowej,

- centrale telefoniczne o pojemności powyżej 10000 numerów i centrale telefoniczne tranzytowe o pojemności 5000-10000 numerów, o znaczeniu miejscowym lub regionalnym,

- garaże podziemne, w których strefa pożarowa przekracza $1500 \mathrm{~m}^{2}$ lub obejmujące więcej niż jedną kondygnację podziemną,

- stacje metra i stacje kolei podziemnych,

- dworce i porty, przeznaczone do jednoczesnego przebywania powyżej 500 osób,

- banki, w których strefa pożarowa zawierająca salę operacyjną ma powierzchnię przekraczającą $500 \mathrm{~m}^{2}$,

- biblioteki, w których zbiory tworzą narodowy zasób biblioteczny [1].

Z biegiem lat zwiększały się wymagania dotyczące systemów SSP. Początkowo ich zadaniem było wykrycie i poinformowanie o wystąpieniu pożaru oraz uruchomienie odpowiednich procedur alarmowych. Obecnie oprócz funkcji podstawowej wymaga się, aby systemy takie wykrywały różne rodzaje pożarów, a także były odporne na działanie zjawisk zwodniczych, które zakłócają pracę systemu i powodują generowanie fałszywych alarmów, obniżając tym samym czujność ludzką. Z jednej strony wymaga się, aby systemy SSP wykrywały zjawiska pożarowe w jak najkrótszym czasie, czyli dąży się do zwiększania czułości detektorów, z drugiej jednak strony dąży się do wyeliminowania reakcji systemu w przypadku wystąpienia zjawisk zwodniczych, czyli pewnego rodzaju „uśpienia” detektorów dla pewnych warunków pracy.

W artykule przedstawiono wpływ różnych zjawisk występujących podczas pożaru na działanie czujek stosowanych w systemach SSP. Badania dotyczące wpływu różnych warunków pożarowych na odpowiedzi detektorów zostały przedstawione między innymi w pracach [2], [3].

Czujka pożarowa stanowi część składową systemu sygnalizacji pożarowej, zawiera co najmniej jeden czujnik, który ciągle lub w odstępach czasu kontroluje co najmniej jedno odpowiednie fizycznie i/lub chemicznie zjawisko towarzyszące pożarom i który przekazuje co najmniej jeden odpowiedni sygnał do centrali sygnalizacji pożarowej [4]. Przed doborem czujek pożarowych do konkretnej instalacji należy określić, jakie czynniki towarzyszące pożarom (produkty spalania) mogą być wykrywane przez czujki. Podstawowe produkty spalania oraz zjawiska towarzyszące spalaniu to: 
- dym zawierający cząstki stałe i gazy pożarowe,

- ciepło,

- promieniowanie elektromagnetyczne w paśmie podczerwieni i ultrafioletu [5].

Do wykrywania powyższych zjawisk stosuje się różne rodzaje czujek między innymi:

- jonizacyjne czujki dymu,

- czujki optyczne dymu działające na zasadzie rozproszenia światła,

- liniowe czujki dymu zawierające nadajnik i odbiornik promieniowania podczerwonego,

- czujki zasysające dym,

- czujki ciepła nadmiarowe i nadmiarowo-różnicowe,

- czujki płomieni IR (ang. Infrared), UV (ang. Ultra-violet), gazu,

- czujki wielodetektorowe, integrujące dwa lub trzy rodzaje czujników.

Częstym negatywnym zjawiskiem występującym w systemach sygnalizacji pożarowej jest pobudzenie czujki i wywołanie fałszywego alarmu przez tzw. zjawisko zwodnicze, którym może być np. para wodna pochodząca z łazienki hotelowej czy kuchni, spaliny samochodowe, dym papierosowy, suchy lód w dyskotekach, aerozole wytwarzane podczas spawania, różnego rodzaju źródła ciepła i wiele innych. Przyczyną fałszywych alarmów może być też pole elektromagnetyczne emitowane przez różnego rodzaju urządzenia elektryczne [6]. Przed wyborem odpowiedniej czujki do konkretnego zastosowania należy na etapie koncepcji przewidzieć możliwość występowania zjawisk zwodniczych. Szczególnie istotne jest to w zakładach produkcyjnych, w których generowane są różnego rodzaju gazy, pyły i zabrudzenia. Od nowoczesnych systemów pożarowych, a w szczególności od zastosowanych detektorów wymaga się, aby były odporne na działanie wszelkiego rodzaju zjawisk zwodniczych i generowały alarm wyłącznie w chwili rzeczywistego zagrożenia pożarowego. Dlatego w miejscach, gdzie takie zjawiska mogą wystąpić, coraz częściej stosuje się wielodetektorowe czujki pożarowe wyposażone $\mathrm{w}$ algorytmy oraz technologię pozwalającą na interpretację zjawisk zachodzących w komorze pomiarowej w czasie rzeczywistym. Czujki takie pozwalają na dynamiczne dostosowanie parametrów w zależności od zachodzących zjawisk, dzięki czemu są dużo bardziej odporne na działanie zjawisk zwodniczych od czujek, w których zastosowano algorytmy tradycyjne. Mają dużo szerszy zakres zastosowania, gdyż zmiana parametrów nie jest statyczna, tylko zmienia się dynamicznie w zależności od sygnałów pochodzących z czujników. W artykule [7] przedstawiono przykłady rozwiązań układów detekcyjnych stosowanych w obszarze wykrywania pożaru.

\section{Opis toru pomiarowego}

Do badań użyto 6 czujek pożarowych stosowanych w systemach SSP:

- czujka nr 1: scattered-light smoke detector - konwencjonalna, optyczna czujka dymu działająca na zasadzie rozproszenia światła, wyposażona $\mathrm{w}$ detektor optyczny, powszechnie stosowana czujka dymu,

- czujka nr 2: neural fire detector - harsh - czujka wielodetektorowa, wyposażona w dwa detektory optyczne do pomiaru rozproszenia światła w przód i wstecz oraz w dwa czujniki ciepła, zwiększające odporność na działanie zjawisk zwodniczych. Czujka przeznaczona do trudnych warunków środowiskowych, działająca w oparciu o dynamiczne dostosowanie parametrów z charakterystyką ustawioną na środowisko brudne,

- czujka nr 3: optical smoke detector - standard - czujka optyczna przeznaczona głównie do wykrywania pożarów generujących dym, wyposażona w czujnik rozproszeniowy w przód z czułością ustawioną na standardową,

- czujka nr 4: neural fire detector - clean - czujka neuronowa wyposażona $\mathrm{w}$ dwa detektory optyczne do pomiaru rozproszenia światła w przód i wstecz, dwa detektory ciepła. Czujka działająca w oparciu o dynamiczne dostosowanie parametrów $\mathrm{z}$ charakterystyką ustawioną na środowisko czyste,

- czujka nr 5: optical smoke detector - sensitive - optyczna czujka dymu, w której czułość została podwyższona przy jednoczesnym ograniczeniu jej odporności na zjawiska zwodnicze,

- czujka nr 6: ionization smoke detector - jonizacyjna czujka dymu, jedna z powszechniej stosowanych czujek wykonana w tradycyjnej technologii. Czujka przeznaczona głównie do wykrywania pożarów z otwartym ogniem.

Czujki zostały rozmieszczone w odległości około $2 \mathrm{~m}$ od stanowiska symulacyjnego. Badania polegały na symulowaniu rzeczywistych pożarów oraz badaniu odpowiedzi czujek na zaistniałe zagrożenie. Podczas testów dokonywano ciągłego pomiaru temperatury $\mathrm{w}^{\circ} \mathrm{C}$ oraz stężenia dymu $\mathrm{w} \% / \mathrm{m}$. Przeprowadzono trzy testy, symulując:

1 - proces spawania,

2 - pożar tlący,

3 - pożar charakteryzujący się otwartym ogniem. 
W przypadku testu 1 zasymulowano proces spawania, który charakteryzuje się emitowaniem wielu zjawisk identycznych do zjawisk generowanych podczas prawdziwego pożaru. $\mathrm{W}$ momencie spawania wydzielane są duże ilości gazów oraz dymu, natomiast nie występuje duży wzrost temperatury (poza obszarem spawania). Podczas testu przerywano proces spawania, co jest typowe dla takiej czynności w warunkach rzeczywistych. Przeprowadzony test symulował wystąpienie zjawiska zwodniczego na działanie czujek pożarowych.

Test 2 polegał na symulowaniu pożaru charakteryzującego się wyłącznie emitowaniem dymu, bez występowania ognia. Do symulacji użyto trzech kawałków bukowego drewna, które umieszczono na rozgrzanej płycie grzewczej. Pożar tlący w początkowej fazie cechuje niewielki prawie zerowy wzrost temperatury oraz duża koncentracja dymu.

Test 3 polegał na symulowaniu pożaru charakteryzującego się otwartym ogniem. Jako ciecz łatwopalną użyto $\mathrm{n}$-heptan. Pożar $\mathrm{z}$ otwartym ogniem cechuje się szybkim wzrostem temperatury oraz emisją trudno zauważalnego dymu. Tego typu pożar jest szczególnie trudny do wykrycia przez czujki optyczne.

\section{Przedstawienie wyników badań}

W trakcie przeprowadzanych badań dokonywano pomiaru temperatury oraz stężenia dymu, a także reakcji czujek na zaistniałe wymuszenie. Wyniki badań zostały przedstawione na wykresach, na których górna część obrazuje zachowanie czujek pożarowych, które mogą znajdować się w jednym z czterech stanów:

- stan nieaktywny (praca normalna), detektor nie jest pobudzony, brak informacji o zagrożeniu - oznaczenie N,

- stan pobudzenia, detektor wykrywa pewne symptomy wystąpienia stanu zagrożenia - oznaczenie P,

- stan ostrzeżenia, czujka informuje o dłużej utrzymującym się stanie pobudzenia, stan wstępnego ostrzeżenia przed pożarem - oznaczenie $\mathrm{O}$,

- stan alarmu, definitywne wygenerowanie alarmu, czujka wykryła pożar - oznaczenie A.

Dolny wykres obrazuje zmierzone czynniki fizykochemiczne.

Stężenie gazów zostało zmierzone w dwóch miejscach jako rozproszenie światła w komorze pomiarowej i zobrazowanych na wykresie jako FW - rozproszenie światła w przód, ang. forward scattering, oraz BW - rozproszenie światła wstecz, ang. backward scattering.
Na ryc. 1 przedstawiono wykresy reakcji czujek na działanie zjawiska zwodniczego, którym było spawanie (test 1 ). Dolny wykres obrazuje pomiary temperatury i stężenia dymu mierzone podczas trzech cykli symulowanego procesu spawania. Cechą charakterystyczną spawania jest dynamiczny wzrost stężenia gazów. Jak przedstawiono na ryc. 1 większość czujek w czasie poniżej 20 sekund przeszła w stan alarmu, czego konsekwencją w rzeczywistych warunkach byłoby wywołanie alarmu I stopnia i konieczność reakcji ze strony służb odpowiedzialnych za bezpieczeństwo budynku. Dla większości czujek gazy emitowane podczas spawania są interpretowane jako pożar, czego efektem jest bezpośrednie przejście ze stanu nieaktywnego w stan alarmu czujki (przejście ze stanu $\mathrm{N}$ w stan A). Tylko czujka nr 2 wyposażona $\mathrm{w}$ technologię dynamicznego dostosowania parametrów oraz przeznaczona do pracy $\mathrm{w}$ trudnych warunkach, pomimo chwilowego pobudzenia nie zasygnalizowała stanu ostrzeżenia. Przeprowadzone badania dowiodły, że w miejscach narażonych na częste zjawiska zwodnicze oraz trudne warunki pracy, tylko stosowanie czujek wielodetektorowych wyposażonych w odpowiednie algorytmy rozpoznawcze gwarantuje uniknięcie fałszywych alarmów.

Na ryc. 2 przedstawiono wyniki badań dla testu 2 polegającego na symulacji reakcji czujek na działanie pożaru tlącego. Dla wymuszonego zjawiska wzrost stężenia gazów w początkowej fazie jest niewielki, dlatego czujki zostały pobudzone dopiero po 50 sekundach. Jako pierwsze zagrożenie pożarowe wykryły czujki optyczne - nr 5, nr 3 oraz czujka nr 4 przy stężeniu gazów na poziomie $3 \mathrm{w} \% / \mathrm{m}$. Badania dowiodły nieprzydatność zastosowania czujki jonizacyjnej do wykrywania tego typu zagrożeń.

Ostatni test polegał na symulowaniu pożaru charakteryzującego się otwartym ogniem, będącego szczególnie niebezpiecznym zjawiskiem ze względu na szybkość rozprzestrzeniania i wzrostu temperatury. Wyniki uzyskanych badań przedstawiono na ryc. 3. Większość czujek wykryła obecność zjawiska zagrożenia w początkowej fazie symulacji pożaru, przy temperaturze $35-40 \mathrm{~W}{ }^{\circ} \mathrm{C}$ oraz niewielkim stężeniu gazów na poziomie $2 \mathrm{w} \% / \mathrm{m}$. Tylko czujka $\mathrm{nr}$ $1 \mathrm{w}$ trakcie przeprowadzanych badań nie wykryła żadnych oznak pożaru, co eliminuje ją w tego typu zastosowaniach. Wartym podkreślenia jest fakt, że detektor wyposażony w technologię dynamicznego dostosowania parametrów z ustawieniami na środowisko czyste wykrył pożar szybciej nawet od czujki jonizacyjnej, która wykorzystywana była często dla tego typu pożarów. 


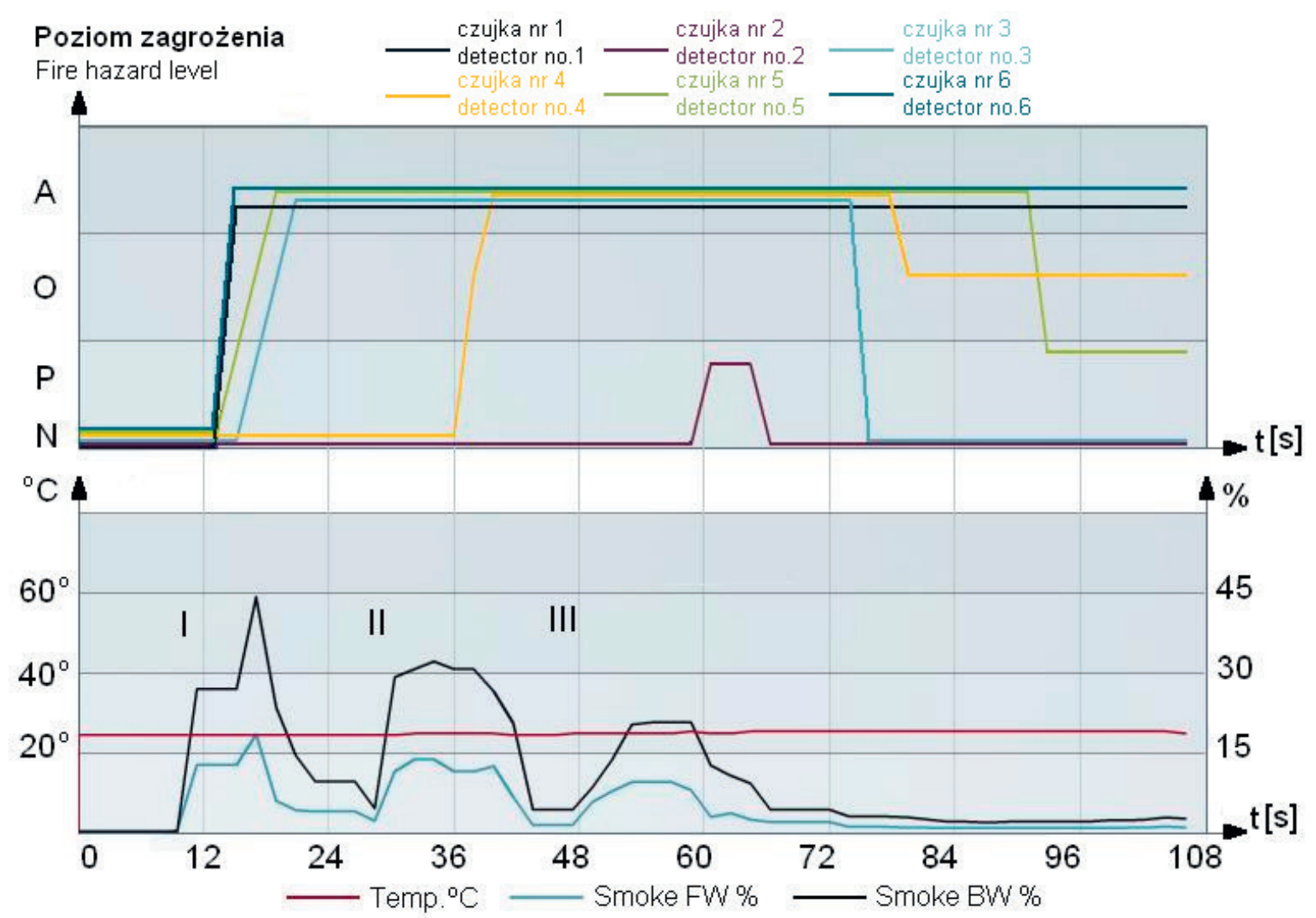

Ryc. 1. Wykres reakcji czujek na wymuszone zjawisko zwodnicze - spawanie [8]

Fig. 1. Detectors' response to the forced deceptive phenomenon - welding [8]

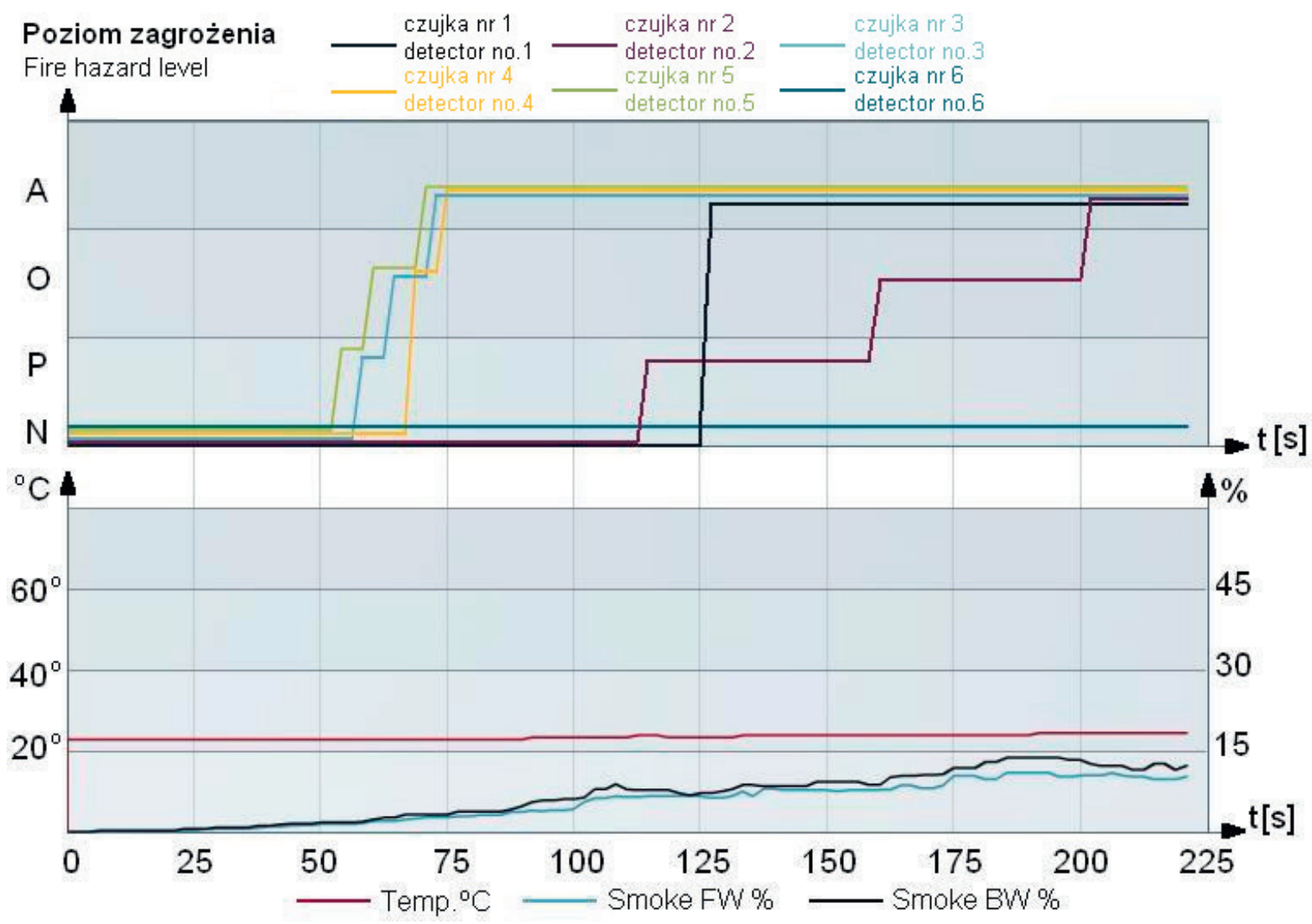

Ryc. 2. Wykres reakcji czujek na pożar tlący [8]

Fig. 2. Detectors' respone to the smoldering fire [8] 


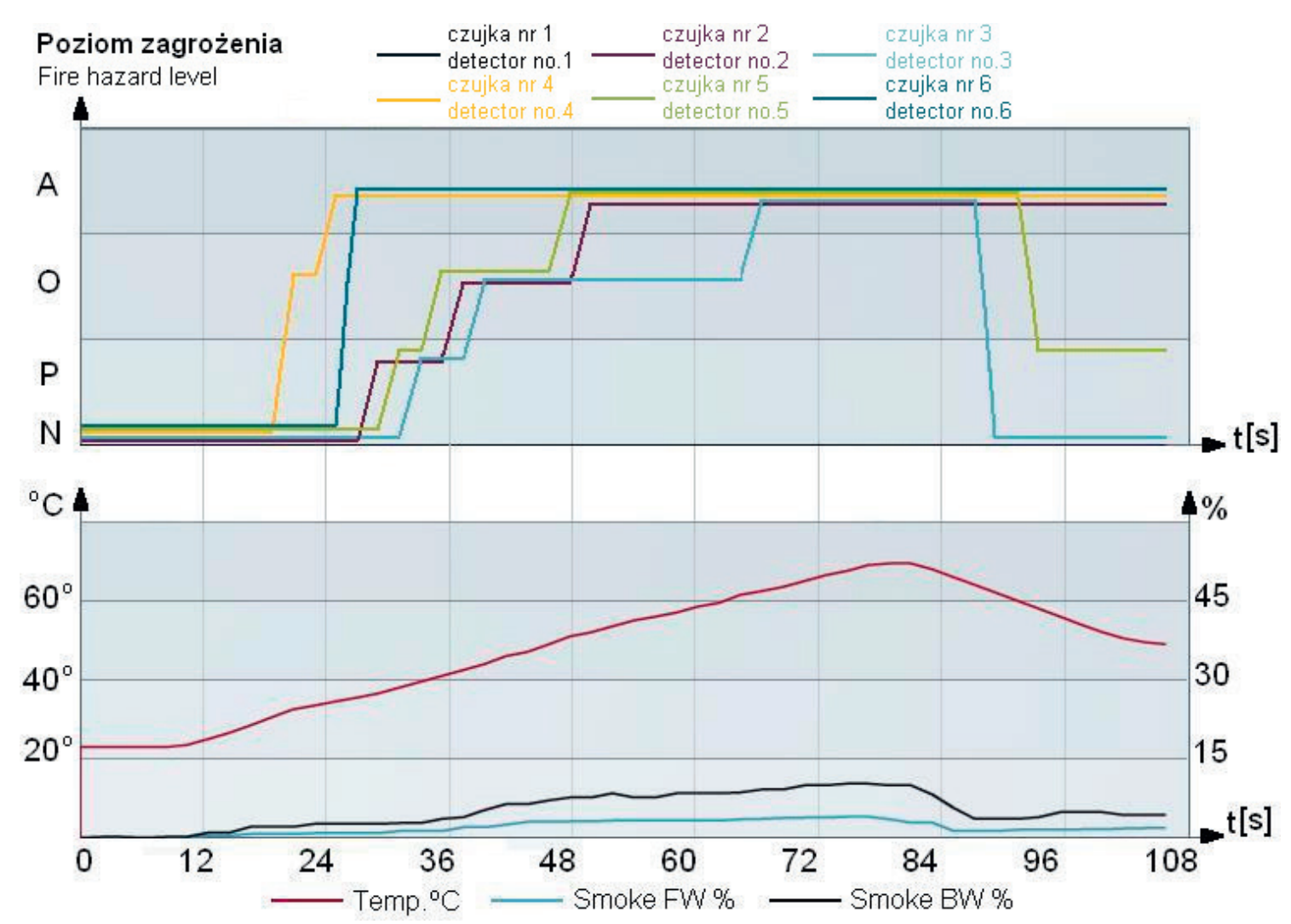

Ryc. 3. Wykres reakcji czujek na otwarty ogień [8]

Fig. 3. Detectors' response to the open fire [8]

\section{Podsumowanie}

Jak najszybsze wykrycie pożaru, detekcja różnych rodzajów zagrożeń pożarowych oraz odporność na zjawiska zwodnicze to trzy podstawowe wymagania stawiane czujkom pożarowym stosowanym w nowoczesnych systemach sygnalizacji pożarowej.

Przeprowadzone badania umożliwiają, szczególnie projektantom i osobom odpowiedzialnym za zabezpieczenie obiektów przed pożarem, na trafniejszy dobór czujek pożarowych do konkretnego zastosowania. Wykonane pomiary dowiodły, że czujki bazujące na nowoczesnej technologii dynamicznego dostosowania parametrów do zmieniających się zjawisk pożarowych wpisują się w szeroki zakres zastosowań, wykrywają pożary charakteryzujące się różnymi zjawiskami i pozwalają na szybsze wykrycie zaistniałego zagrożenia $\mathrm{w}$ porównaniu do

\section{Literatura}

[1] Rozporządzenie Ministra Spraw Wewnętrznych i Administracji z dnia 7 czerwca 2010 r. w sprawie ochrony przeciwpożarowej budynków, innych obiektów budowlanych i terenów (Dz.U. $2010 \mathrm{nr} 109$ poz. 719). tradycyjnych czujek. Ich szczególną zaletą jest duża odporność na zjawiska zwodnicze, co pozwala na stosowanie ich w wymagających środowiskach. Optyczne czujki konwencjonalne mają ograniczone zastosowanie w środowisku przemysłowym, gdyż są narażone na działanie zjawisk zwodniczych, przez co mogą generować fałszywe alarmy pożarowe.

Wykonane badania dowiodły, że tylko rzetelna analiza możliwych zagrożeń pożarowych, rozpoznanie czynników oraz zjawisk, jakie mogą wystąpić podczas pożaru, a także znajomość procesów rozprzestrzeniania ognia może przyczynić się do odpowiedniego doboru czujek. Jest to o tyle istotne, że trafny dobór detektorów może spowodować wcześniejsze wykrycie zagrożenia pożarowego, ograniczając tym samym zniszczenia spowodowane pożarem oraz zwiększając szanse na ugaszenie i ochronę życia i mienia ludzkiego.

[2] Cleary, T. G., Results From a Full Scale Smoke Alarm Sensitivity Study. Suppression and Detection Research Application: A Technical Working Conference, 13th Annual. SUPDET 2009. Proceedings. Fire Protection Research 
Foundation. February 24-27, 2009, Orlando, FL, 2009.

[3] Cleary T. G., Grosshandler W. L., Chernovsky A., Smoke Detector Response to Nuisance Aerosols. International Conference on Automatic Fire Detection "AUBE '99", 11th. Proceedings. University of Duisburg. [Internationale Konferenz uber Automatischen Brandentdeckung.] March 16-18, 1999, Duisburg.

[4] PN-EN 54-1:2011 Systemy sygnalizacji pożarowej - Część 1: Wprowadzenie.

[5] Wytyczne SITP WP - 02:2010 - Wytyczne projektowania instalacji sygnalizacji pożaru, czerwiec 2011.
[6] Kośnik J., Fałszywe alarmy pożarowe, BiTP Issue 2, 2007, pp. 179-188 [dok. elektr.] http:// czytelnia.cnbop.pl/czytelnia/5/94 [dostęp 03.09.2013].

[7] Turkiewicz R., Innowacyjne technologie majace zastosowanie w obszarze wykrywania zagrożenia pożarowego, BiTP, Issue 1, 2007, pp. 283-298 [dok. elektr.] http://czytelnia.cnbop.pl/czytelnia/15/81 [dostęp 09.09.2013].

[8] Dokumentacja techniczna, materiały firmy Siemens.

dr hab. inż. Bolesław Karwat, prof. AGH - kierownik Zamiejscowego Ośrodka Dydaktycznego AGH w Mielcu, Sekretarz Kolegium Dziekanów Wydziałów Mechanicznych Polskich Uczelni Technicznych, Przewodniczący Rady Programowo-Naukowej Uniwersytetu Trzeciego Wieku w Mielcu, Prezes Zarządu Fundacji Wydziału Inżynierii Mechanicznej i Robotyki AGH, Członek Rady Funduszu Stypendialnego im. St. Staszica AGH. Zainteresowania badawcze koncentruje na zagadnieniach dynamiki układów elektromechanicznych, modelowania systemów wytwarzania, szeroko rozumianej ochrony środowiska przyrodniczego.

mgr inż. Artur Górski - od 2008 roku Product Manager systemów sygnalizacji pożarowej, a od 2010 roku Kierownik Działu Wsparcia Technicznego CPS FS w Siemens Sp. z o.o. Od wielu lat prowadzi szkolenia z zakresu systemów sygnalizacji pożarowej. Specjalista w zakresie m.in. systemu Cerberus PRO produkcji Siemens. Czynnie współpracuje z wieloma biurami projektowymi i firmami wykonawczymi, udzielając wsparcia merytorycznego na każdym etapie projektu.

mgr inż. Emil Stańczyk - absolwent Akademii Górniczo-Hutniczej im. Stanisława Staszica w Krakowie, student studiów doktoranckich Wydziału Inżynierii Mechanicznej i Robotyki AGH. Obszar prowadzonych badań: wykorzystanie urządzeń adsorpcyjnych oraz absorpcyjnych w systemach chłodniczych, optymalizacja procesów. Zainteresowania: automatyka w budownictwie, systemy zabezpieczeń obiektów wojskowych. 